Original Research Paper

\title{
Sub-National Legislature and Democratic Consolidation in Nigeria's Fourth Republic: Lessons from Osun State House of Assembly
}

\author{
${ }^{1}$ Bolaji Omitola and ${ }^{2}$ Olusola R. Ogunnubi \\ ${ }^{1}$ Department of Political Sciences, Osun State University, Osogbo, Nigeria \\ ${ }^{2}$ Politics and International Studies, University of Zululand, South Africa
}

\author{
Article history \\ Received: 20-12-2015 \\ Revised: 03-11-2016 \\ Accepted: 05-11-2016 \\ Corresponding Author: \\ Olusola B. Ogunnubi \\ Politics and International \\ Studies, University of Zululand, \\ South Africa \\ Email: olusola.ogunnubi@yahoo.com
}

\begin{abstract}
This paper examines the contribution of sub-national legislature in reinforcing democratic consolidation in Nigeria by drawing lessons from the Osun state legislature in South-West Nigeria. Specifically, the authors interrogate changing party composition, oversight actions and executive reactions and constituencies' activities of members of the Assembly across three terms of twelve years: 1999-2003; 2003-2007 and 2007-2011. The analysis presented in the paper reveals that relationship between the Osun state legislature and executive has been defined by dominance by the latter manifested through financial dependence of the Assembly in carrying out legislative activities, overdependence on the executive for maintenance of members and their offices, domination of legislative agenda with executive bills and other executive oriented activities as well as reliance on the executive to guarantee legislative members' political career. The paper concludes that in spite of the foregoing drawbacks, the Osun state legislature remains relevant to the consolidation of democracy in Nigeria especially in its contributions towards legitimising, supporting and stabilising the polity and serving as deliberative arena for securing government policies and programmes.
\end{abstract}

Keywords: Sub-National Legislature, Democracy, Consolidation, Osun State, Nigeria

\section{Introduction}

In Nigeria, in spite of more than twelve years of democratic rule, the concern of most perceptive observers of the country's nascent democracy is how to ensure its consolidation and prevent the reversal to autocratic rule. However, for any effort aimed at democratic consolidation to succeed, it must not only involve the people but must be driven by, orient to and ultimately owned by the people. It is imperative to note that of all the institutions of democratic governance, the legislature is expected to be the most representative as well as closest to the people and therefore occupy the best position in terms of aggregating, reflecting and projecting the people's interests. The extent to which the Nigerian variant of democratic rule and its legislative institution have allowed this development constitutes the central thrust of this paper.

Primarily, the paper is concerned with examining the roles of the Osun state house of assembly in Nigeria in the current democratic dispensation. This involves investigating how it has fared in pursuing the objectives of its establishment as a legislative house by examining its law-making, oversight activities, investigative functions necessary for the deepening democratic consolidation in Osun state in particular and Nigeria as a whole.

Arising from the general thrust of this paper therefore, certain questions are raised in the assessment of the continued relevance of the legislature in the Nigerian democratic project. These are: is the role of the legislature in Osun state House of Assembly declining along the line of the world pattern? On what basis can the continued relevance of the Assembly in the current Fourth Republic governance in Osun state be justified? What are the specific challenges facing the assembly in Osun state since the inauguration of the Fourth Republic? What are the avenues for improvement in the performance of the various constitutional roles of the Assembly?

The study adopts both historical and descriptive analysis based on quantitative methodology derived from 
interviews of legislators and legislative workers in the State Assembly as well as public laws enacted by the State Assembly while qualitative data were drawn from documentary sources such as newspapers, government publications-house's votes and rules of proceeding, books and journals. This paper is therefore concerned with examining the role of parliament or legislature as a democratic institution in entrenching democratic practice in the country. The paper therefore examines the contributions of sub-national legislature in Nigeria towards Nigeria's democratic project, drawing lessons from the Osun state legislature in the South-West Nigeria between 1999 and 2011. For analytical purpose, this paper is divided into four sections; the foregoing introductory section is followed by a theorisation of democracy. The third section examines the legislature and efforts at democratic consolidation in Nigeria while the fourth part offers a periodic analysis of the Osun state House of Assembly covering 1999 to 2003; 2003 to 2007 and 2007 till 2011. The paper concludes with a reflection on the challenges and prospects of the State Assembly as an agent for furthering democratic consolidation.

\section{Legislative Governance and Democratic Consolidation}

Democracy as a concept or a system is devoid of any generally acceptable definition among most scholars. Thus, democracy has been interpreted by different people to suit their different situations and interests. Gitonga's (1998:5) aptly notes that there are a great variety and diversity of regimes and systems that pass for democracies. Therefore, establishing the precise conditions and objective meaning of democracy is not an easy task. However, there is a need to consider some definitions especially in order to put the focus of this paper in perspective. For instance, Bobbio (cited in Caron et al., 1992:424) defines democracy as "a cluster of rules permitting the broadest, surest, direct and indirect participation of majority of the citizens in political decisions, for example in decisions affecting the whole country". To a great extent, this definition conforms with the classical definition ascribed to Abraham Lincoln that democracy is government of the people, by the people and for the people. Thus, central to these definitions of democracy is the role of the people in governance through one avenue or the other. It is within this context that Momoh (2006:63) concludes that "democracy whether classical or social democratic, popular or socialist, talks about representative government and empowerment of the people". In other words, direct democracy practiced in ancient Athens and Greek city states has become impossible in the modern societies; therefore the principle of representation has become central to the operations of modern democracy. Legislature as a representative institution is thus central to the realisation of democratic objective of government.
Many factors have been identified as preconditions for democratic experiment to succeed; top among these conditions is socio-economic and political factors. According to scholars such as Huntington (1968); Gurr (1980) and Kaur (2007), democratic states must have viable and supportive political and democratic institutions. Of these political and democratic institutions which include parliament, the presidency, judiciary, political parties, interest associations and the armed forces among others, the parliament (legislature) is very prominent (Huntington, 1968; Gurr, 1980; Kaur, 2007; Ogundiya, 2010).

Thus, Bratton (1998) sees the process (of democratic consolidation) as where democracy becomes so broadly and profoundly legitimate among its citizens that it is unlikely to breakdown. In another way, democratic consolidation implies the political process of making a nation's democratic practices succeed on a continuous basis, without midway breakdowns occasioned by undemocratic incidents like coup d'état (Dode, 2010:188).

While arguing that democratic consolidation is a function of the peculiarity of the country under study, Ogundiya (2010:7), maintains that "in transiting societies like (Nigeria) where the threat of coup persists, consolidation may be seen as the process of eliminating opposition to democracy on the part of powerful actors" Thus, the process of making democracy acceptable to the people overtime without considering a reverse to the undemocratic era is referred to as consolidation. However, Momoh (2006:70) while reviewing the perfunctory role of democracy in Nigeria's Fourth Republic argues that the continuation of democratic rule in a country does not necessarily leads to democratic consolidation. For him, adopting the term 'de-democratisation', “...the so-called democratic rule actually works against democracy, democratic institution and democratic practices".

The authors do not disagree with Momoh's assessment of Nigeria's democracy which is also similar to Peter Anyang Nyang'o's parody of transformation of elected civilians into "presidential authoritarianism"-a situation best expressed in the eight years of Obasanjo's presidency in Nigeria and tagged "Kabiyesi Presidency" (This denotes a president that is accountable to none). However, we recognise the general perception that democracy would more likely continue as the preferred system of governance (Lewis and Alemika, 2003). This paper while noting that there exists largely some imperfections in the democratic system in both intent and purpose proceeds from Owoeye's (2010) admission that, democratic consolidation or sustainability in Nigeria is viewed in the context of seamless transfers not just from military to civil rule but also from one civil administration to another to the extent that Nigeria would eventually consolidates its electoral process for greater efficiency. 
In this regard, legislature is a very important institution of democracy as it has responsibilities of representing the diverse interests of members' constituencies while performing other legislative functions such as law making, approval of budgets and appointments, impeachment process and oversight functions. Thus, legislature is central to democratic sustainability and consolidation because of its being the most representative as well as the closest to the people. However, the reality of the situation in Nigeria like other countries that have witnessed several democratic overthrows by the praetorian soldiers is that the legislature is the least developed institution as a result of severe mutations and due to stoppage of the legislative operations whenever the military took over while the other institutions are allowed to function within the military rule.

\section{Historicising Osun State and the Legislature}

Created from the old Oyo state in 1991, Osun State is located in Nigeria's South West geographical zone; a zone that was originally part of the Western Region at independence in 1960. The region which had earlier contact, relationship and association with Western culture, tradition and institution, also had a rich traditional culture, institution and processes. The reason for combining both the European and traditional sociocultural and political milieu has been ascribed to the similarities existing between the colonial culture and tradition and that of the majority Yoruba's and Benin that occupied the old Western Region and the SouthWestern geo-political zone. Therefore, having a background of traditional monarchical system of sociopolitical organisation coupled with democratic ideals bequeathed by long association with the British during colonisation, the Yoruba, including the present Osun state which is the focus of our study have developed a robust practice of party activities and parliamentarian tradition. This, in spite of relatively short period of existence of Osun state House of Assembly has impacted the sophistication and development of legislative business in the State legislative House.

It was during the aborted third republic in Nigeria that the Osun State First Assembly was inaugurated. The first assembly was inaugurated on 15th January, 1992 following a proclamation by the first Executive Governor of the State, AlhajiIsiaka Adeleke. The house had a brief life span as it was dissolved with other democratic structures with the termination of the third republic on 17th November, 1993.

In the first assembly, undemocratic exchanges dominated relationship between the legislature and the executive in Osun State. It could be said that the State Assembly was an irritant not only in Osun state but in the whole states of the federation as it was later discovered that the military were not committed to transferring power to the civilian as the tortuous transition in the third republic continued without an end (Oyediran, 1999).

Following the collapse of the Third Republic and the emergence of Abacha's military regime, five political parties were registered: United Nigerian Congress Party (UNCP), the Democratic party of Nigeria (DPN), the National Centre party of Nigeria (NCPN), the Grassroot Democratic Movement (GDM) and the Coalition for National Consensus (CNC) (Anifowoshe and Enemuo, 1997:217). The emergence of these parties and their leadership were linked to Abacha's administration. Hence, Bola Ige was of the view that the political parties represent "five fingers of a leprous hand". The connection with the Abacha's administration became more glaring and at a stage all of the five political parties unanimously adopted General Sanni Abacha as their Parties' Presidential candidate, thereby making presidential election unnecessary. All of these developments created some cynicism in the country and while the death of General Abacha in June 1998 effectively put an end to these parties, the emergence of General Abdulsalam Abubakar as Head of state heralded a new transition programme, resulting in the registration of People's Democratic Parties (PDP), the All People's Party (APP) and the Alliance for Democracy (AD).

\section{Executive-Legislature Relations in Osun State First Assembly (1999-2003): Dispensation of Commotion}

The successful conduct of gubernatorial election led to the emergence of Chief Bisi Akande as the second Executive Governor of Osun State in May 1999. The Assembly was inaugurated on 31st of May 1999 Governor, while Barrister (Dr.) Mojeed Olujimi Alabi became the speaker of the 26 member legislative house (Unfortunately, a member of the Assembly at inauguration, Hon. Odunayo Omobolanle Olagbaju representing Ife Central constituency from May 31 1999December 19, 2001 was killed on December 19, 2001 following a factional crisis in the ruling party, the Alliance for Democracy). As Table 1 shows, the Assembly composed of 24 members from the AD, two from ANPP while the PDP had a member.

The second Assembly of Osun State inaugurated in the year 1999 had similar features with the first Assembly of 1991. One of the features is that it was dominated by members of the ruling party that produced the governor, the Alliance for Democracy (AD). However, in spite of the control enjoyed by the party that produced the Governor in the assembly, the relationship between the legislature and the executive was less cordial; in fact there were allegations and counter allegations from both arms of the government. There were irreconcilable differences across the two divides in spite of intervention of notable leaders of the Alliance for Democracy, influential leaders and Obas (traditional rulers) of the state. 
Table 1. Names, constituencies and party affiliations of members of Osun state second assembly

\begin{tabular}{lll}
\hline Name & Constituencies & Party affiliation \\
\hline Hon. (Dr.) MojeedAlabi & Ejigbo & AD \\
Hon. Moses OladipoGbotoso & Ilesa East & AD \\
Hon. BusariOlawuwo Hassan & Ifelodun & AD \\
Hon. (Barr.) RafiuAdejare Bello & Ede North & ANPP \\
Hon. (Barr.) Anthony B. A. Taiwo & Ife North & AD \\
Hon. AliyuAyobamiTewogbade & Irewole/Isokan & AD \\
Hon. MaroophdeenAderojuLawal & Olorunda & AD \\
Hon. (Barr.) Simeon OlufemiPopoola & Boluwaduro/Boripe & AD \\
Hon. TheophilusAdegokeAwotunde & Oriade & AD \\
Hon. TajudeenAyofeAdisa & Iwo & AD \\
Hon. Joseph O. Fakayode & Ifedayo & AD \\
Hon. Julius AdemolaAjibodu & Ife South & AD \\
Hon. (Engr.) MoshoodOlayiwola & Osogbo & AD \\
Hon. (Barr.) Joshua AdemolaAdedeji & Ila & AD \\
Hon. (Prince) OluAkintolaOmolaoye & Egbedore & AD \\
Hon. AzeezOladipoPopoola & Irepodun/Orolu & ANPP \\
Hon. Johnson AjagbeOjo & Ede South & AD \\
Hon. Josiah Olalekan Oyediran & Odo-Otin & AD \\
Hon. OdunayoOmobolanleOlagbaju & Ife Central & AD \\
Hon. Komolafe Richard Obafemi & (May31, 1999-Dec.19 2001) & AD \\
Hon. (Chief) TaiwoOlajireAlawode & Atakunmosa East/West & PDP \\
Hon. AkindiyaAdediran Amos & Aiyedire & AD \\
Hon. (Mrs.) Omobanike O. Tejuoso & Olaoluwa & AD \\
Hon. Akinpelu O. Sunday & Obokun & AD \\
Hon. Ezekiel Akinola Awoniyi & Ayedaade & AD \\
Hon. (Engr.) OlalekanAfolabiOmidiora & Ilesa West & AD \\
Hon. RopoOyewole Ebenezer & Ife East & Ife Central \\
\hline Soure: Author compilation (2011) & (2002-May 2003) &
\end{tabular}

Source: Authors' compilation (2011)

The first effect of this frosty relationship was in the delay in approval of list of commissioners nominated by the Governor.

The interference of external actors cannot be discountenanced in the frosty relationship between the executive and the legislature in the second Assembly of Osun State. Honourable members of the same party were working at cross purposes to the executive. Such actions have always been trailed by allegations of monetary inducement of the members of the house to pursue certain objectives that are linked to personal interests of certain individuals in or outside the government.

The high point of the crisis which almost grounded the operation of the state was the impeachment proceeding against the Governor in November 2000. Another crisis was a fall out of the killing of the Federal Minister of Justice and Attorney General of the federation Chief Bola Ige who hailed from the state on December 24, 2001. The crisis even led to the impeachment of the Deputy Governor Otunba Iyiola Omisore. However, Omisore impeachment bored more of the imprint of the outcome of the faceoff he had with the Governor Bisi Akande and other leaders of the Alliance for Democracy Party in Osun State. For instance, there were allegations that because Omisore bankrolled the election of Akande to the office of Osun state governor, there were expectations of a better return on his investment than the post of Deputy Governor without any portfolio could afford.

The relationship between the executive and the legislature of the second Assembly 1999-2003 was initially cordial until after the completion of legislatives quarters which houses members of the legislature and within walking distance of the house of Assembly complex. The government of Bisi Akande then discontinued the payment of (N90, 000) housing and transport allowances to the legislature. This action obviously did not enjoy the support of the legislatures who felt cut off from a veritable means of access to the state resources. Another issue which also has to do with politics of patronage was the inability of the Bisi Akande administration to allow members of the house access to some percentage from contracts awarded by the government. It must be noted that this practice of the legislature conniving with contractors or the executive in implementations of government projects or policies has become a norm in the Nigerian political system (Dudley, 1982). This collusion has affected the performance of the oversight functions of the assembly over ministries, departments and agencies of government. Even when the 
house of the assembly embarks on probes of some of these MDA it has been confirmed that the end of such probe is to gain access to some of the funds allegedly misappropriated by the MDA. This was the case with the probe of the contracts awarded for power projects put in place by the House of Representatives.

Pointedly, the experience between the legislature and executive highlighted above aptly illustrates the truism in Laswell's position that politics is about who get what, when and how. This is because, in the main, party politics is devoid of principles, ideas or any known ideology; legislators act without reference to party affiliation or party position on any issue. They often throw overboard all the finest of legislative rules and procedures in the constitution and those established by them for the conduct of their own affairs. Therefore, the legislature has consistently displayed the attitude of 'anything goes'. Hence, the usual degeneration of differences among them to a motor parks scenario of 'free for all fight'. Most of these differences and ensuing fights are usually not about defending the interests of the people or disagreement on government policies but about personal selfish interests hence the appellation given to the legislative house in Nigeria is 'Ghana must go Assembly' (This is used to describe the acts of stuffing bribe money in a polythene bag popularly named Ghana must go). The money sharing mentality has often compromised commitment to one of their statutory functions of oversight of the activities of government and its agencies.

The allegations levelled against the Governor, Chief Bisi Akande included woeful performance, disregard for financial regulations, administrative incompetence and above all the refusal of the Governor to assent to the selfaccounting bill passed by the legislature. Also, included in the allegations are that there was absence of public/human relationship between the Governor and the legislators; that the Governor had not been guided by the constitution in his actions and the refusal of the Governor to carry out the resolutions to sack some members of the executives especially the Commissioner of Finance.

However, some observers of the several face-offs between the legislature and the executive in the Second Osun Assembly would not agree with the foregoing argument. From the various interviews of past legislators and some officers of the Assembly, it is alleged that the root cause or the major contributory factors to the crisis can be located in the inexperience of the major dramatis personae of the period, the lack of maturity of some of the legislators and more importantly the high handedness of the executive Governor, Chief Bisi Akande, in his relationship with the legislative house (Interview, 2011). It was also observed that the undue dependence of the legislature on the executive for funding of its activities contributed to the constant impasses experienced during the period. For instance, one of the respondents mentioned an instance where an officer in the legislative house could not order for the repair of the air conditioner unit in the office of the speaker costing only N50, 000 without first seeking approval from the governor office (Interview, 2011).

Also it is observed that contrary to the pattern of most democracies and especially the developing variant like Nigeria, most of the bills and legislative inputs came from the executive of Osun State (Table 2). Thus, the executive governor along with the executive council represent the major source of policy formulation, implementation and execution. It is therefore not surprising that the legislature was perceived by the people as irritants and unnecessary appendage in the running of government. For instance, the private member bills introduced by the legislature and even legislative self-accounting and public/political officers' remuneration package were denied assent by the governor. The governor claimed that the "selfaccounting bill' is merely a self-seeking law to usurp the functions of the executive particularly for promoting legislators propensity for awarding contracts (Magazine, 2000:12). However, the impeachment threat against the governor could not be carried through, apart from the fact that the impeachment was defeated at the floor of the House of Assembly as 13 members of the House voted in support of the Governor while 12 members voted against him. Thus, the peace move embarked upon by the Governor to appease members of the Assembly eventually yielded fruitful dividend as the Governor and the Speaker of the House of Assembly jointly delivered a press conference to assure the public that all was now well in the State (Newswatch, 2000:173). Overall, the impeachment process was clearly arm twisting means of forcing government of Bisi Akande to do the bidding of the legislators as the allegations against the government did not border on corruption or any case of malfeasance.

\section{Executive-Legislature Relations under the Third Osun State Assembly (2003-2007): Period of Romance}

The result of the general election conducted in 2003 was unprecedented in the political history of the country and especially in the South-West geo-political zone of the country. This was due to the fact that for the first time in its political history, the South West zone joined the ruling party (PDP) at the federal level. However, there were contestations about the genuineness or otherwise of the election result. More so, when the AD governors who lost out to their counterpart PDP flag bearers felt short-changed in an agreement they had to give their support and thus ensure an home base for the then President Olusegun Obasanjo in the Presidential election. 
Table 2. Laws enacted by the second assembly in Osun state

Law Authentication, February 2000

Osun State House of Assembly (Self Accounting Law), June 2000

Year 2000 Appropriation Law

Public/Political Office Holders (Remuneration package) Law, November 2000

Advisory Council of the State in the Prerogative of Mercy Law, July 2000

Customary Courts (Amendment) Law, December 2000

Year 2000 Supplementary Appropriation Law, December 2000

Appropriation Law, 2001

Pension (Governor and Deputy-Governor) Law, May 2001

Osun State Independent Electoral Commission Law, July 2001

Public/Political Office-holders (remuneration package) (Amendment) Law, July 2001

Local Government (Administration) Law, November, 2001

Osun State Environmental Protection Agency (Amendment) Law, September 2001

Political Officer-holder (Remuneration package) (Amendment) Law, No. 27 Law.

Education (Primary Schools) (Special Provisions) (Amendment) Law, November, 2001

Osun State Council of Obas and Chiefs Edict (Repeal) Law, January 2002

Rent Control and Recovery of Premises Law

Osun State Order of Precedence of Public Officers and other Personal Law

Local Government (Administration) (Amendment) Law, March 2002

Osun State Agricultural Development Corporation Law, June 2002

Appropriation Law 2002, May 2002

Revised Edition of the Laws Law, December 2002

Electoral Law, December 2002

Auditor-General for Local Governments (Abolition and Re-designation of Office) Law

Public/Political Office-holders (Remuneration package) (Amendment) No. 37 Law

Permanent Board of Enquiry (Abolition and Prohibition, etc) Law

Their grouse was that while they met their parts of the bargain of not presenting a candidate for the presidency and also mobilising the South-West to vote for the President to secure a second term ticket, the President worked against their victories at the polls employing various state instruments, agencies such as police, military and other security apparatus not to mention a wholesale rigging and other fraudulent electoral malpractices to rob them of their victories. However, in the spirit of their pact with the president, none of the defeated governors of Oyo, Ondo, Ogun, Osun and Ekiti contested the outcomes of the elections. It was therefore not surprising that the PDP swept twenty-five out of the twenty-six seats of the House of Assembly (Table 3). The third assembly which was inaugurated on 3rd June 2003, by the candidate of the Peoples Democratic Party, Prince Olagunsoye Oyinlola, had Barrister Rafiu Adejare Bello as the speaker.

From the profile of members of the third assembly, one can conveniently conclude that the Assembly was a one party assembly. This is because out of the 26 members only one member belonged to the Alliance for Democracy. In fact from interview of one of the respondents, it was observed that the so called Alliance for Democracy member indeed belonged to the People's Democratic Party and only answered as Alliance for Democracy so that there would be a semblance of tolerance for the opposition and more so to allow the member access to the paraphernalia and perquisites attached to the office of Minority leader.

It was within the political context, that the period of the third Assembly in Osun from 2003 to 2007 witnessed high level of political repression, intolerance of opposition and excessive use of force by the PDP led government of Prince Olagunsoye Oyinlola. In fact, the third Assembly was perceived to be more of a rubber stamp institution compared to other three assemblies that have existed in Osun state's political history. The Assembly was at the mercy of the executive as led by the governor and party chieftain in discharging its constitutional responsibility. In virtually all issues, directives often came from the governor and party chiefs such as Chief Ademola Rasaki popularly known as 'Landero'. All bills, approval of commissioners and other appointment were done with little or no delay as there were virtually no opposition in the Assembly.

Also, contrary to the situation in the second Assembly, there was harmonious working relationship between the legislature and the executive-a situation described as outcome of maturity in terms of internalising the legislative roles by the legislators of the third assembly by one of the respondents interviewed. However, other respondents argued that the legislators could not do otherwise as most of them were largely beholding to and had allegiance to the governor who was responsible in many ways for their victories at the poll. 
Table 3. Names, constituencies and party affiliations of members of Osun state third assembly

\begin{tabular}{llll}
\hline Name & Post & Constituency & Party affiliation \\
\hline Rt. Hon. RafiuAdejare Bello & Speaker & Ede North & PDP \\
Hon. TaiwoYekeenSunmonu & Olorunda & Deputy Speaker & PDP \\
Hon. Ropo Ebenezer Oyewole & Ife Central & Majority Leader & PDP \\
Hon. Michael OluwoleOgunsemi & Oriade & Minority Leader & AD \\
Hon. Adegoke Hassan Olusola & Ifelodun & Chief Whip & PDP \\
Hon. SuleimonAdioOyegunle & Irewole/Isokan & Deputy Majority Leader & PDP \\
Hon. SojiAdagunodoOluwatukesi & Obokun & Deputy Chief Whip & PDP \\
Hon. AdesoyeOyetunde & Ayedire & Senatorial Whip (West) & PDP \\
Hon. Joshua O. Ogunleye & Atakunmosa (East/West) & Senatorial Whip (East) & PDP \\
Hon. (Mrs.) FunmilayoOlaseinde & Ifedayo & Senatoiral Whip (Central) & PDP \\
Hon. RafiuOlaideFatoki & Ede South & Member & PDP \\
Hon. Isaac Ajayi (Sawoolarun) & Ilesa West & Member & PDP \\
Hon. Musa OlawaleOlanrewaju & Ilesa East & Member & PDP \\
Hon. DaudaOlawale Ibrahim & Irepodun/Orolu & Member & PDP \\
Hon. (Prince) AdeniranIbitoye & Odo-Otin & Member & PDP \\
Hon. Sunday OlufemiOroniyi & Iwo & Member & PDP \\
Hon. BakareAkandeAleem & Ejigbo & Member & PDP \\
Hon. Adeoye Adelakun & Osogbo & Member & PDP \\
Hon. Bashir F. Adeyela & Ife East & Member & PDP \\
Hon. Julius OyebanjiAkinremi & Ife North & Member & PDP \\
Hon. Benjamin OlufemiFarombi & Adedaade & Member & PDP \\
Hon. Rufus OlayinkaOgunwole & Boluwaduro/Boripe & Member & PDP \\
Hon. YinusaAdebisi & Ife South & Eember & PDP \\
Hon. OkunladeObiremi & Ila & Member & PDP \\
Hon. IsmailaKolawole & Olaoluwa & Member & PDP \\
Hon. Samuel Adebayo Amuda & & PDP
\end{tabular}

Source: Authors' compilation (2011)

Table 4. Laws enacted by the Osun state third assembly

Local Government Administration (Amendment) 2003

Pension (Governor and Deputy Governor) Amendment 2003

Council of Obas Recomposition Bill

Electoral Law Amendment Bill

Order of Precedence

Local Government Administration (Amendment) 2003

Agency for Poverty Reduction

Osun State Council of Obas Decomposition

2004 Supplementary Appropriation 2004

Year 2004 Appropriation Bill 2004

Osun State Girl Child Marriage (Prohibition) 2004

Osun State Female Circumcision (Prohibition) 2004

Osun State Agricultural Development Programme Bill

Osun State Agricultural Development Corporation Bill

Osun State Secret Cult Prohibition Bill

Osun State School of Health Technology (Establishment)

2005 Appropriation Bill (2005)

Osun State Micro-Credit Agency Establishment (2005)

Year 2005 Supplementary Appropriation (2005)

Year 2006 Appropriation Law (2006)

Osun State Local Government Staff Loans Board (2006)

Osun State Registration/Renewal of Business Premises

Osun State House of Assembly Service Commission (Establishment) (2006)

Osun State University (Establishment) (2006)

Year 2006 Supplementary Appropriation (2006)

Osun State Year 2007 Appropriation (2007)

District Customary Court/Customary Court (Establishment) (2007)

Customary Court of Appeal (Establishment) (2007)

Osun State University Development Fund (Establishment) (2007)

Year 2007 Supplementary Appropriation (2007)

Osun State Universal Basic Education Bill 
Also, from the interviews of the staff and aides of members of the Osun State Third House of Assembly (Interview, 2011), the Assembly functioned essentially to complement the agenda of the governor without any serious questioning. This is contrary to the situation in the second Assembly where in spite of the fact that the House was controlled by the party that formed the government, the legislators and the executive disagreed on a lot of issues.

The harmonious relationship between the executive and legislative house was so high that the governor who was returned for the second time in the year 2007 had to make it a reference point while addressing the members of the Fourth Assembly at inauguration on 4th June, 2007 (OSHA, 2007). As Table 4 shows, a total number of 31 bills were enacted. He asked the Fourth Assembly to build on the legacy left by the Third Assembly which includes mutual understanding, legislative duties and effective execution of constituency projects. From the foregoing, it was clear that there was a convergence of interests of the executive and the legislative arms in the Third Assembly in Osun State between 2003 and 2007.

\section{Executive-Legislature Relations in Fourth Assembly of Osun State (2007-2011)}

After the conduct of series of election in the 2007 General election, the Peoples' Democratic Party again won the majority seat in the assembly with 15 seats while the Action Congress, a party that emerged from the former Alliance for Democracy won 11 seats. The names, constituencies, party affiliations and changes to the composition of the 26 members Osun State Fourth Assembly are indicated in Table 5. The Assembly and gubernatorial elections in Osun State in 2007 was widely contested among the two prominent parties in the South West at the period (PDP and AC). The fallout of this contest and claim of irregularities especially by opponent of the ruling PDP is the unending litigations that trailed the election. It must be noted that the 2007 General Elections in Nigeria attracted the highest number of litigations in the country. Osun state represented one of the states that contributed to this all-time record.

The result of these litigations on the Assembly was that the party affiliations of members of the assembly changed drastically from the position at inauguration on 4 th of June 2007. For instance in 2010, three Action Congress members representing Osogbo, Ejigbo and Egbedore lost their seats to the re-run ordered by the Appeal Court in Ibadan. Also, coming in the wake of another legal victory which eventually gave victory to the Action Congress of Nigeria (after the change of name to Action Congress of Nigeria) at the gubernatorial election meaning that the tenure of Prince Olagunsoye Oyinlola from 2007 to November 2011 was illegal having being declared that Mr. Rauf Aregbesola won the election. There was another spate of decamping of members from the PDP to the ACN. Notable among these were members from Ayedaade, Boripe/Boluwaduro, Irewole/Isokan and Ifedayo constituencies.

Table 5. Names, constituencies and party affiliations of members of Osun state fourth assembly

\begin{tabular}{lll}
\hline Name & Constituencies & Party \\
\hline Rt. Hon. RafiuAdejare Bello & Ede North & PDP \\
Hon. Roopo Ebenezer Oyewole & Ife Central & PDP \\
Hon. J. OladipoOgunleye & Atakunmosa (East/West) & PDP \\
Hon. Benjamin OlufemiFaronbi & Ayedaade & PDP (ACN) \\
Hon. AdemolaAkanmuOgundeji & Boripe/Boluwaduro & PDP (ACN) \\
Hon. Najeem Salam [George Alabi) & Ejigbo & AC (PDP) \\
Hon. SikiruOkunladeAraoye & Olaoluwa & PDP \\
Hon. Ayobami S. Salinsile & Iwo & AC \\
Hon. AbiodunAwolola (OkunObiremi) & Egbedore & AC (PDP) \\
Hon. GbadeboKolawoleOyejide & Irewole/Isokan & PDP (ACN) \\
Hon. IdiatYemisiBabalola & Ede South & PDP \\
Hon. OmololaAdekunle & Ayedire & PDP \\
Hon. OlatunjiAdewaleOgunleye & Oriade & PDP \\
Hon. Adeyemi F. Fafowora & Ilesa-West & AC \\
Hon. Femi Fafiyebi & Obokun & AC \\
Hon. Aaron DiranAyanbeku & Ife South & PDP \\
Hon. Timothy Owoeye & Ilesa East & AC \\
Hon. IpoolaAderemiBinuyo & Ife North & PDP (ACN) \\
Hon. Martins OlajideAdeyeye & Ife East & PDP \\
Hon. AkintundeAdegboye & Osogbo & AC \\
Hon. Ajibola O. Kolawole & Olorunda & AC \\
Hon. MukailaAdegbolaOyekunle & OdoOtin & PDP \\
Hon. Tope KamilOyedele & Orolu/Irepodun & AC \\
Hon. Abiodun Samuel Idowu & Ifedayo & PDP (ACN) \\
Hon. Ajiboye O. A. & Ila & AC \\
Hon. AdeyemiAkinlolu & Ifelodun & PDP \\
\hline Sore: Auh & &
\end{tabular}

Source: Authors' Compilation (2011) 
There was no real opposition in the Fourth Assembly as party affiliations of members was persistently in a state of flux, thanks to the unending litigations that characterised the tenure of the assembly and carpet crossing by members from the party constituting the government to the opposition. The legislature could not perform effectively its oversight functions or challenged the activities of the executive. A very interesting case emerged when local government chairmen in the state bought brand new Brilliance cars for their respective wives on the platform of Women Development in the respective 30 local governments in the states. The claim by the chairmen that the cars were bought to facilitate the smooth running of the various Women Department could not convince the House. This led to questioning of the commissioner of local government affairs, Prof. Muib Opeloye and the ALGON Chairman, Alhaji Teslim Igbaloye. At the end of this summon, the local government chairmen were merely upbraided for diverting about N400 million that could be used in bringing about development to the communities in their various areas of jurisdiction into an illegal venture under the guise of performing statutory functions by their respective wives. Interestingly, the House could not sanction the local government chairmen since they were also beneficiaries of the same type of brilliance cars bought for them by the executive (The Guardian, 2009).

As a result of development like the foregoing the Assembly could not serve as effective watchdog on the other arms of government especially the executive and by extension failed to be an effective check on corruption. Another factor that may also account for the lacklustre performance of the assembly especially the opposition party ACN members maybe due to the incessant intimidation involving arrests and detention of opposition members of the house. This might have affected concentration and attention of the opposition in serving as effective watchdog of the ruling party-the Peoples Democratic Party. The statement of the Speaker of the house in one of their proceedings further points to the fact that even the opposition party, the ACN cannot be totally exonerated from the unholy alliance between the legislature and the executive of this period. He commented though jokingly that "what went between them (the opposition and the Governor Oyinlola) in the last two years, I never had that kind of opportunity as the Speaker" (OSHA, 2011).

\section{Osun State House of Assembly: Performance, Problems and Prospects}

This section provides a critical examination of the performance, problems and prospects of the Osun State House of Assembly and their implications for democratic sustenance and good governance in the country. To begin with, the composition of membership of the House from 1999-2003, 2003-2007 and 2007 and 2011 reveals a number of trends. First is that there was consistency in the preponderance of male membership to the extent that there have always been one female member-representing a mere $3 \%$ of the population of the House in each chamber of the second, third and fourth assemblies of Osun State.

Second is that in terms of social status of members of the Assembly in the second, third and fourth Assemblies, elite who ranged from Doctor of Philosophy, Medical Doctors, Lawyers, Engineers, Principal of Schools, Teachers, Journalists, Manager of Businesses, Nurses and others have occupied the chambers to the exclusion of lower stratum of the society, such as peasants, farmers, artisans workers or workers' leaders, youth and leaders of civil societies group.

In terms of output measured in the number of bills that were passed into laws, the performance of the House is rather not too impressive. This is judging from the fact that much attention when not devoted to unending crisis and tango with the executive as witnessed in the legislative years of 1999 to 2003 would be wasted in passing resolutions that do not have any force of law on the executive or its agents. It is therefore not surprising that for the twelve years, 1999 to 2011 under focus; only 78 bills were passed into laws while from 1999 to 2003, a period of four years over 100 motions were passed.

Also, a closer examination of the bills that were eventually passed into laws would reveal that most of them had to do with advancement of personnel welfare of the members of the House, some on ensuring the convenience of their staff and the public service at large while few actually touched/addressed socio-economic and development challenges of the people of Osun State.

Another interesting revelation from studying Osun State House of Assembly from 1999 to 2011 indicate that whereas the Assembly started with 16 parliamentary standing committees in 1999 to 2003 and that by 2011 the committee number is now 22 , these committees are not fully operational as only the chairmen and secretaries of most committees met while other members are perpetually absent. However, the only exception to the rule is the accounts, finance and appropriation committee which meet regularly through the period under review. Lastly, these committees were dominated largely by members of the ruling party, while contrary to the situation in the United States of America where Nigeria copied presidentialism, the accounts, finances and appropriation committee is headed by member of the ruling party instead of the opposition party (Akinsanya and Davies, 2002). Thus, the purpose of committee system contribution to legislative business is not well utilised.

In the performance of the oversight functions, the House has not been effective in the performance of this role. Contrarily, the executive has often failed to implement their 
recommendations. The oversight functions which involve probing the activities of the executive, also includes conduct of investigation and according to Section 128(1) of the 1999 Constitution that empowers each House of National Assembly or the State's House of Assembly to conduct investigations into any matter within its competence. A good example is the case of the refusal of Governor BisiAkande to sack his Commissioner of Finance in spite of the fact that the Assembly upon investigation of activities of the commissioner found him culpable. Even when the oversight functions have been extended to impeachment of the executive or threat of impeachment, we could observe that this has been due to political reason(s) than as a result of enforcing sanctions due to non-compliance with the oversight functions of the assembly in the Second Assembly.

In terms of representative functions, the Assembly did not achieve much, though there was a provision for establishment of constituency offices, but from observations of the operation of the activities of constituencies in three senatorial districts of Odo-Otin, Oriade and Ede South Local Governments, it was discovered that where constituency offices were established, they were merely for symbolic reasons as no meaningful legislative support activities took place at the offices. Therefore, the legislative constituencies failed to serve as source of inputs from the constituents to the functions of the members in the assembly. In most cases, instead of employing legislative assistants to coordinate the constituent offices, the study reveals that the offices were populated by members of families, hanger on and relatives of the members of the House of Assembly. In other words, there was no institutionalised means put in place for the masses to contribute to improving the law making functions of the members of the house.

Another manifestation of executive dominance in the workings of the Osun State House Assembly of the various dispensations under study is the legislature's lack of control over government revenue or the budget process in the state. The governors often violated the provision of budgets passed by the assembly, while the major contents and line items in the budgets remained unknown to the legislatures.

In spite of the foregoing challenges, the Assembly has been partly a source of stability for the state at different periods. The Assembly was able to resolve different conflicts in spite of persisting differences among members. For instance, the impeachment crisis of the Second Assembly was resolved without leading to violence or resulting in federal government imposing a state of emergency as it was the case in Plateau State (North Central Nigeria). Also, it is important to note that there was harmonious relationship between the legislative and the executive in the third and fourth Assemblies. Of particular importance is the Fourth Assembly which in spite of presence of formidable opposition of the $11 \mathrm{ACN}$ members as against the ruling PDP 15 members, was devoid of crisis. The harmonious relationship thus worked to ensuring stability of the overall Osun State system as against the case of neighbouring states such as Ogun where its Fourth Assembly witnessed persistent crises in spite of the fact that it was a one party Assembly. One of such crises eventually led to the closure of the Ogun State Assembly for a record period of nine months.

Thus, the Osun House of Assembly has been a focal point of deliberating on government policies, where no matter how feeble, some of these policies could be challenged as well as avenue through which people can access information on government activities and a rallying point for legitimising the activities of Osun State Government. However, the performance of the functions of the Assembly will be better improved if identified practices and laws already put in place for positioning the Assembly for good governance are effectively implemented. These areas include the current practices of joint sitting with the executive in the Treasury Board Meetings to iron out grey areas on finances and appropriations. Second, is by ensuring effective implementation of Osun State House of Assembly Service Commission Laws of 2010. This will lead to a carrier oriented and robust service that can in turn assist in effective delivery of the functions of the Assembly.

\section{Conclusion}

Sub-national legislatures in Nigeria as the Osun State example reveals, has very often been reduced to the arena for constant fierce contests, shrewd bargaining and allocation of spoils among its members. Whereas, the legislators at the national level have consistently rein in the executives in spite of the fact that the ruling party that control the executive also control majority in the legislature, the same cannot be said of the Osun Assembly in the third and fourth Assemblies. The two assemblies have abdicated their roles of being institutional check on executive authority or help to ensure accountability in governance.

\section{Acknowledgement}

The author has no acknowledgement to report.

\section{Funding Information}

No funding was received for this project.

\section{Author's Contributions}

Both authors contributed to the design and drafting of the manuscript. All authors gave approval for the final submitted draft. 


\section{Ethics}

This article is work of the authors with no contribution from any other person. The authors declares no conflict of interest with any institution for the publication of this paper.

\section{References}

Akinsanya, A. and A. Davies, 2002. Legislative-Executive Relations. In: Nigerian Government and Politics 19791983, Akinsanya A. and G.J. Idang (Eds.), Wusen Publishers, Calabar, ISBN-10: 9780511563, pp: 448.

Anifowoshe, R. and F. Enemuo, 1997. Elements of Politics. 1st Edn., Sam Iroanusi Publications, Lagos, pp: 217.

Bratton, M., 1998. Second elections in Africa. J. Democracy, 9: 51-66. DOI: 10.1353/jod.1998.0041

Caron, B., A. Gboyega and E.E. Osaghae, 1992. Democratic Transition in Africa.1st Edn., CREDU Documents in Social Sciences and Humanities, Ibadan, pp: 424.

Dode, R., 2010. Political Parties and the Prospects of democratic Consolidation in Nigeria: 1999-2006. Afr. J. Polit. Sci. Int. Relat., 4: 188-194.

Dudley, B.J., 1982. An Introduction to Nigerian Government and Politics. 1st Edn., Indiana University Press, Bloomington, ISBN-10: 0253284007, pp: 367.

Gitonga, A.K., 1998. The Meaning and Foundation of Democracy -- Democratic Theory Practice in Africa. Nairobi, Kenya, Heinemann.

Gurr, T., 1980. Handbook of Political Conflict: Theory and Research. 1st Edn., "The" Free Press, New York, ISBN-10: 0029127602, pp: 566.

Huntington, S.P., 1968. Political Order in Changing Societies. 3rd Edn., Yale University Press, New Haven, pp: 488.
Interview, 2011. Interview of legislative aids. Interview of Some Officers of the Assembly.

Kaur, S., 2007. Institutional development as a challenge to democratic sustenance in Nigeria. Int. Stud., 44: 217-233. DOI: 10.1177/002088170704400302

Lewis, P. and E. Alemika, 2003. Seeking the Democratic Dividend: Public Attitudes and Attempted Reform in Nigeria. 1st Edn., IDASA, Cape Town, pp: 49.

Momoh, A., 2006. Democracy, de-democratisation and development in Nigeria. Nigerian J. Int. Affairs, 32: 61-85.

Magazine, N., 2000. Lagos Nigeria Tribune. 1st Edn., Ibadan, pp: 10.

Ogundiya, S.I., 2010. Political Parties, Institutionalisation and Democratic Consolidation: Theoretical Nexus and Nigeria's Experience in the Fourth Republic. In: Political Parties and Democratic Consolidation in Nigeria, Ogundiya, S.I. (Ed.), Codat Publications, Ibadan, pp: 6-9.

OSHA, 2007. Proceedings of Osun State House of Assembly Official Report. Publications Department, Osun State House of Assembly.

OSHA, 2011. Proceedings of Osun State House of Assembly Official Report. Publications Department, Osun State House of Assembly.

Owoeye, J., 2010. Democratic consolidation in Nigeria: The challenges of 2011 general election. Uniosun J. Polit. Society.

Oyediran, O., 1999. Nigeria: Politics of Transition and Governance, 1986-1996. 1st Edn., CODESRIA, Dakar, ISBN-10: 2869780710, pp: 340. 